\title{
Ixekizumab for Psoriatic Arthritis: Safety, Efficacy, and Patient Selection
}

John Miller ${ }^{1,2}$

Abin P Puravath'

Ana-Maria Orbai (iD ${ }^{1,3}$

'Division of Rheumatology, Johns Hopkins University School of Medicine, Baltimore, MD, USA; ${ }^{2}$ Lyme Disease Research Center, Johns Hopkins University School of Medicine, Baltimore, MD, USA; ${ }^{3}$ ssoriatic Arthritis Program, Johns Hopkins University School of Medicine, Baltimore, MD, USA
Correspondence: Ana-Maria Orbai Johns Hopkins Division of Rheumatology, 5200 Eastern Avenue, MFL Center Tower Suite 4100, Baltimore, MD, 21043

Tel + I 410550823 I

Fax + 1 4I0 5502072

Email aorbail@jhmi.edu
Objective: Ixekizumab is a monoclonal antibody targeting IL-17A and licensed for psoriasis, psoriatic arthritis (PsA) and axial spondyloarthritis. Review objectives were to summarize: 1) ixekizumab safety in people with PsA, 2) ixekizumab efficacy from Phase III randomized controlled trials, and 3) ixekizumab study participant PsA phenotypes.

Methods: We conducted a search in PubMed limited to phase III randomized controlled trials (RCT) and corresponding long-term extension studies where the intervention was treatment with ixekizumab in a population with PsA.

Results: We identified 17 publications and 13 met inclusion criteria. Injection site reactions (ISR) and allergic reactions occurred in up to $25.3 \%$ and $6.2 \%$ with ixekizumab and $4.5 \%$ and 1.85 , respectively, with placebo. ISR occurred in $9.5-10.6 \%$ at 24 and 52 weeks with ixekizumab versus $3.2-3.5 \%$ with adalimumab $(\mathrm{p}<0.01)$ in biologic-naïve PsA. Serious adverse events at 24 weeks occurred in $8.5 \%$ with adalimumab versus $3.5 \%$ with ixekizumab $(p=0.02)$, and at 52 weeks in 12.45 with adalimumab and 4.25 with ixekizumab $(p<0.01)$. Ixekizumab had similar efficacy to adalimumab across all PsA musculoskeletal, symptom and patient-reported outcome domains and surpassed adalimumab in psoriasis outcomes as well as all combined musculoskeletal and psoriasis outcomes. The study subject population was overwhelmingly white, balanced men-women, BMI at the obese threshold, had on average 7-year PsA duration and 15-year psoriasis duration. Disease activity was high with 7/66 swollen joints, 13/68 tender joints, 55\% enthesitis, variable dactylitis (12-51\%), and active psoriasis in $>92 \%$.

Conclusion: Ixekizumab treatment in PsA was associated with a statistically significant higher risk of injection site reactions versus placebo or adalimumab. Ixekizumab had statistically significantly fewer serious adverse events than adalimumab. Ixekizumab demonstrated efficacy for all PsA disease activity domains as well as for slowing radiographic disease progression. The main shortcoming of the ixekizumab PsA program is lack of representation of African American study participants.

Keywords: ixekizumab, psoriatic arthritis, interleukin-17 inhibitor, clinical trials, biologic therapy

\section{Introduction}

Psoriatic arthritis is an inflammatory arthritis characterized by its association with the skin disease psoriasis and disease-specific manifestations including enthesitis, dactylitis, and axial spondyloarthritis. Multiple psoriatic arthritis patterns emerge based on combinations of these manifestations, leading to disease heterogeneity in presentation and outcomes. ${ }^{1}$

Treatment selection in PsA is guided by several considerations, ${ }^{2-4}$ including 1) disease activity and breadth of domains involved, 2) the existence of prior damage (a sign of disease severity), 3) clinical phenotypes such as axial or enthesitis-predominant 
disease, 4) prior treatment experience (PsA is regarded as more difficult to treat as patients advance to subsequent treatments), 5) comorbidities, 6) patient preference, and importantly, 7) treatment availability. Treatment for PsA is chronic and individuals with PsA frequently have comorbidities, ${ }^{5}$ making safety an important objective, in addition to efficacy, for any treatment being considered.

Ixekizumab is a humanized IgG4 monoclonal antibody that selectively binds interleukin 17A (IL-17A) preventing its interaction with the IL-17 receptor. Ixekizumab is labeled by the US Food and Drug Administration for the treatment of psoriasis (including in children age six and above), psoriatic arthritis, ankylosing spondylitis and nonradiographic axial spondyloarthritis. ${ }^{6}$ Specifically for the treatment of PsA, ixekizumab was studied in two phase III randomized controlled trials (RCTs), one each in biologicnaïve and TNF inhibitor-experienced populations, and one open-label, blinded-assessor head-to-head study comparing ixekizumab to adalimumab ${ }^{7}$ in biologic-naïve people with PsA.

\section{Rationale, Mechanism of Action and Pharmacokinetics}

The IL-17A molecule and IL-17 receptor were discovered in 1993 and 1995, respectively, and prompted awareness of their role in human autoimmune disease and the subsequent characterization of a new type of $\mathrm{T}$ helper lymphocytes, the CD4+Th17 cells. More recently, a number of additional immune cells with an IL-17 cytokine signature have been characterized, including innate immune $\mathrm{T}$ cells (gamma delta $\mathrm{T}$ cells, natural killer cells, group 3 innate lymphoid cells/ILC3), myeloid lineage cells including neutrophils and microglia, and tissue resident memory $\mathrm{T}$ cells. Although immunologic signaling through members of the IL-17 cytokine family is incompletely understood, it has been suggested that IL-17 cytokines operate at the interface of innate and adaptive immunity and have great importance in human health and disease. ${ }^{8,9}$ There is a homeostatic role for IL-17 in health, which includes neutrophil recruitment and host defense, maintenance of epithelial barrier functions in the skin and mucosa/intestine, wound healing, epithelial proliferation, metabolism, including thermogenesis and adipose regulation, and microbiota balance. ${ }^{9,10}$ However, under conditions of chronic inflammation IL-17 signaling can mediate and amplify pathologic responses, leading to, or potentiating autoimmunity, tumorigenesis and tissue remodeling. To date, IL-17 has been implicated in psoriasis, psoriatic arthritis, ${ }^{11-15}$ rheumatoid arthritis, ${ }^{16}$ tumorigenesis, ${ }^{17,18}$ bone erosion, pathologic tissue remodeling, and neurodegeneration. ${ }^{9}$

Modulating IL-17 signaling in pathologic states has led to unprecedented therapeutic results with IL-17A inhibitors ixekizumab and secukinumab in psoriasis, far surpassing TNF inhibition, ${ }^{19}$ and provided additional therapeutic options in PsA and spondyloarthritis. In PsA, IL-17A inhibition was as good as the standard of care TNF inhibition for active inflammatory musculoskeletal disease (including arthritis, enthesitis, dactylitis, disease signs, symptoms, and patient-reported outcomes) in two head-tohead clinical studies. ${ }^{7,20}$

Ixekizumab is a humanized IgG4 with $98.2 \%$ of the molecule containing human germline sequences. It has an engineered serine-to-proline mutation in the hinge region of the heavy chain, to prevent half antibody formation. Ixekizumab has low-binding ability for Fc gamma receptors or components of the complement system, making it unlikely to cause any immune activation. Central to its therapeutic mechanism of action, ixekizumab has high binding affinity for human IL-17A, preventing interaction with the IL-17RA receptor and downstream signaling. ${ }^{21}$

Ixekizumab is administered via subcutaneous injection. The labeled dosing regimen in adults with PsA or ankylosing spondylitis consists of an upfront $180 \mathrm{mg}$ loading dose followed by $80 \mathrm{mg}$ every 4 weeks. In nonradiographic spondyloarthritis, there is no upfront loading dose, while maintenance is the same as in PsA. In contrast, for moderate and severe plaque psoriasis, there is an intermediate "loading" with ixekizumab $80 \mathrm{mg}$ every 2 weeks for 12 weeks, between the initial loading dose of $160 \mathrm{mg}$ and final maintenance dose of $80 \mathrm{mg}$ every 4 weeks. Peak ixekizumab serum concentrations have been observed on day \#4 after the $160 \mathrm{mg}$ loading dose. Serum steady state concentrations were achieved 8 weeks after the loading dose with every 2 weeks dosing (psoriasis indication) and 10 weeks after switching from every 2 weeks to every 4 weeks maintenance. Bioavailability after subcutaneous injection ranged from $60 \%$ to $81 \%$ in psoriasis and was higher via injection in the thigh versus abdomen. Clearance and volume of distribution increased as body weight increased. Frequency of ixekizumab anti-drug antibodies in PsA was $11 \%$ at 52 weeks of treatment, while frequency of neutralizing antibodies was $8 \%{ }^{6}$ 


\section{Identification of Phase III Randomized Controlled Trials (RCTs) of Ixekizumab in PsA}

We performed a PubMed search with search terms "ixekizumab" and "psoriatic arthritis" and limits of "clinical trials". The search retrieved 17 publications of which four were excluded (two dermatology trials, one biomarker study, and one study not reporting primary efficacy results). Thirteen publications were included: two primary reports of pivotal ixekizumab RCTs; ${ }^{22,23}$ one primary report of a controlled blinded-assessor open-label ixekizumab versus adalimumab head-to-head study; ${ }^{7}$ two analyses of patient outcomes through the end of the placebo controlled RCT period; ${ }^{24,25}$ and eight long-term efficacy and safety analyses of the ixekizumab RCT and open-label study datasets. ${ }^{26-33}$

\section{Ixekizumab Safety}

Treatment emergent adverse events evaluated included: deaths; infections: any infections, candidiasis, esophageal candidiasis, upper respiratory infection, nasopharyngitis, sinusitis, bronchitis, pneumocystis pneumonia, active and latent TB urinary tract infections; organ toxicity: cytopenia, liver toxicity, interstitial lung disease; inflammatory bowel disease; malignancy; cerebro-cardiovascular events and major acute cardiovascular events; depression; tolerability: injection site reactions and allergic and hypersensitivity reactions.

Results up to 24 weeks from the SPIRIT-P1 and P2 trials are summarized in Table 1. Up to 24 weeks, there were no deaths, no occurrence of major cardiovascular adverse events, no inflammatory bowel disease, no interstitial lung disease, no pneumocystis pneumonia, and no active or latent TB. ${ }^{22,23,33}$

Table I Treatment Emergent Adverse Events with Ixekizumab and Placebo Through 24 Weeks in People with Biologic-Naïve or TNFiExperienced Psoriatic Arthritis

\begin{tabular}{|c|c|c|c|c|}
\hline Safety Outcomes at 24 Weeks ${ }^{33}$ & $\begin{array}{l}\text { Placebo } \\
\mathrm{N}=224\end{array}$ & $\begin{array}{l}\text { IXEQ4WK } \\
\mathbf{N}=\mathbf{2 2 9}\end{array}$ & $\begin{array}{c}\text { IXEQ2WK } \\
\mathbf{N}=225\end{array}$ & $\begin{array}{l}\text { IXE Combined } \\
\qquad N=454\end{array}$ \\
\hline Any infection, $n(\%)$ & $62(27.7 \%)$ & 77 (33.6\%) & $72(32 \%)$ & 149 (32.8\%) \\
\hline Serious infection & 0 & I (0.4\%) & $5(2.2 \%)$ & $6(1.3 \%)$ \\
\hline Candidiasis & I (0.4\%) & $4(1.7 \%)$ & $8(3.6 \%)$ & $13(2.6 \%)$ \\
\hline Esophageal candidiasis & 0 & 0 & I $(0.4 \%)$ & I (0.2\%) \\
\hline Upper respiratory infection & $16(7.1 \%)$ & $16(7.0 \%)$ & $15(6.7 \%)$ & $31(6.8 \%)$ \\
\hline Nasopharyngitis & $9(4.0 \%)$ & $15(6.6 \%)$ & $7(3.1 \%)$ & $22(4.8 \%)$ \\
\hline Bronchitis & $7(3.1 \%)$ & $4(1.7 \%)$ & $7(3.1 \%)$ & II (2.4\%) \\
\hline Sinusitis & $5(2.2 \%)$ & $9(3.9 \%)$ & $6(2.7 \%)$ & $15(3.3 \%)$ \\
\hline Urinary tract infection & $5(2.2 \%)$ & $8(3.5 \%)$ & $4(1.8 \%)$ & $12(2.6 \%)$ \\
\hline Cytopenia & $2(0.9 \%)$ & $2(0.9 \%)$ & $4(1.8 \%)$ & $6(1.3 \%)$ \\
\hline Hepatic events & $10(4.5 \%)$ & $7(3.1 \%)$ & II (4.9\%) & $18(4.0 \%)$ \\
\hline Cerebro-cardiovascular events & $2(0.9 \%)$ & 0 & 0 & 0 \\
\hline Depression & $3(1.3 \%)$ & $4(1.7 \%)$ & $4(1.8 \%)$ & $8(1.8 \%)$ \\
\hline Malignancies (excludes NMSC) & 0 & $2(0.9 \%)$ & 0 & $2(0.4 \%)$ \\
\hline Injection site reactions* & $10(4.5 \%)$ & 40 (17.5\%) & 57 (25.3\%) & 97 (21.4\%) \\
\hline Allergic or hypersensitivity reactions** & $4(1.8 \%)$ & $10(4.4 \%)$ & 14 (6.2\%) & $24(5.3 \%)$ \\
\hline
\end{tabular}

Notes: Bold font designates statistically significant differences as calculated in the primary publications: *Injection site reactions were significantly more frequent versus

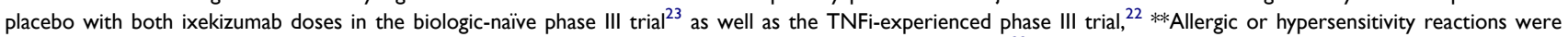
significantly more frequent versus placebo with both ixekizumab doses in the TNFi-experienced phase III trial. ${ }^{22}$ Up to 24 weeks, there were no deaths, no occurrence of major cardiovascular adverse events, no inflammatory bowel disease, no interstitial lung disease, no pneumocystis pneumonia, and no active or latent TB. ${ }^{22,23,33 .}$

Abbreviations: TEAEs, treatment emergent adverse events; NMSC, non-melanoma skin cancer; IXE, ixekizumab; IXEQ4W/IXEQ2W, ixekizumab 80 mg every 4 or every 2 weeks; ADA, adalimumab. 
In the SPIRIT-P1 study, the totality of TEAEs for each active treatment arm was statistically significant higher versus placebo (ixekizumab $80 \mathrm{mg}$ every 2 weeks or every 4 weeks: $66-67 \%$ versus placebo $47 \%, \mathrm{p}</=0.01$; adalimumab $40 \mathrm{mg}$ every 2 weeks: $64 \%$ versus placebo $47 \%, p=/<0.025$ ). There was significantly more frequent occurrence of injection site reactions and allergic reactions with ixekizumab administration (up to $25.33 \%$ and $6.2 \%$ respectively with ixekizumab every 2 weeks) versus placebo ( $4.5 \%$ and 1.85 respectively). The excess injection site and allergic reactions were statistically significant with ixekizumab versus placebo in each study separately for both the biologic naïve PsA population and the TNFi-experienced population, whereas adalimumab rates were comparable to placebo (see Table 1).
Ixekizumab compared directly to adalimumab at 24 and then at 52 weeks showed TEAEs were similar to the above. Differences between proportions of any adverse events in the ixekizumab and adalimumab intervention groups were not statistically significant in the head-to-head study, except for more TEAEs with ixekizumab by week 24 (69.6\% versus $61.1 \%, p=0.04)$ with no difference at week 52 , more serious adverse events with adalimumab significant at both 24 and 52 weeks $(8.5 \%$ versus $3.5 \%, \mathrm{p}=0.02$; and $12.4 \%$ versus $4.2 \%$, $\mathrm{p}<0.01$ ), and significantly more injection site reactions with ixekizumab versus adalimumab at both 24 and 52 weeks (9.5\% versus $3.2 \%, \mathrm{p}<0.01$; and $10.6 \%$ versus $3.5 \%, \mathrm{p}<$ 0.01 ) (p-values calculated using Fisher exact test for comparison of proportions were all greater than 0.05 ) (see Table 2).

Table 2 Treatment Emergent Adverse Events with Ixekizumab or Adalimumab Through 24 Weeks in People with Biologic-Naïve Psoriatic Arthritis (SPIRIT-H2H) 7,31

\begin{tabular}{|c|c|c|c|c|c|c|c|c|c|c|}
\hline \multirow{3}{*}{$\begin{array}{l}\text { Safety Outcomes } \\
\text { Treatment } \\
\mathrm{N}, \%\end{array}$} & \multicolumn{5}{|c|}{24 Weeks $^{7}$} & \multicolumn{5}{|c|}{52 Weeks $^{31}$} \\
\hline & \multicolumn{2}{|c|}{$\begin{array}{l}\text { IXE* } \\
\mathrm{N}=\mathbf{2 8 3}\end{array}$} & \multicolumn{2}{|c|}{$\begin{array}{c}\text { ADA } \\
\mathbf{N}=\mathbf{2 8 3}\end{array}$} & \multirow[t]{2}{*}{ p-value } & \multicolumn{2}{|c|}{$\begin{array}{c}\text { IXE } \\
N=283\end{array}$} & \multicolumn{2}{|c|}{$\begin{array}{c}\text { ADA } \\
\mathbf{N}=\mathbf{2 8 3}\end{array}$} & \multirow[t]{2}{*}{ p-value } \\
\hline & $\mathbf{n}$ & $\%$ & $\mathbf{n}$ & $\%$ & & $\mathbf{n}$ & $\%$ & $\mathbf{n}$ & $\%$ & \\
\hline Any TEAEs & 197 & 69.6 & 173 & 61.1 & 0.04 & 209 & 73.9 & 194 & 68.6 & 0.19 \\
\hline Serious AEs & 10 & 3.5 & 24 & 8.5 & 0.02 & 12 & 4.2 & 35 & 12.4 & $<0.01$ \\
\hline Discontinuation due to AEs & 7 & 2.5 & 13 & 4.6 & 0.26 & 12 & 4.2 & 21 & 7.4 & 0.15 \\
\hline Infections & 102 & 36.0 & 87 & 30.7 & 0.21 & 119 & 42.0 & 111 & 39.2 & 0.55 \\
\hline Serious infections & 4 & $\mathrm{I} .4$ & 8 & 2.8 & 0.38 & 5 & 1.8 & 8 & 2.8 & 0.58 \\
\hline Candida infections & 7 & 2.5 & 2 & 0.7 & 0.18 & 7 & 2.5 & 3 & 1.1 & 0.34 \\
\hline Injection site reactions & 27 & 9.5 & 9 & 3.2 & $<0.01$ & 30 & 10.6 & 10 & 3.5 & $<0.01$ \\
\hline $\begin{array}{l}\text { Allergic/hypersensitivity } \\
\text { reactions }\end{array}$ & 7 & 2.5 & 11 & 3.9 & 0.47 & II & 3.9 & 13 & 4.6 & 0.84 \\
\hline $\begin{array}{l}\text { Cerebrocardiovascular } \\
\text { events }\end{array}$ & 3 & I.I & 5 & 1.8 & 0.73 & 5 & 1.8 & 7 & 2.5 & 0.77 \\
\hline Malignancies & 0 & 0 & 3 & I.I & - & 0 & 0 & 4 & 1.4 & - \\
\hline Depression & 3 & I.I & 7 & 2.5 & 0.34 & 5 & 1.8 & 9 & 3.2 & 0.42 \\
\hline IBD & 2 & 0.7 & 0 & 0 & - & 2 & 0.7 & 0 & 0 & - \\
\hline Crohn disease & 1 & 0.4 & 0 & 0 & - & I & 0.4 & 0 & 0 & - \\
\hline Ulcerative colitis & 1 & 0.4 & 0 & 0 & - & I & 0.4 & 0 & 0 & - \\
\hline Cytopenias & 5 & 1.8 & 11 & 3.9 & 0.20 & 9 & 3.2 & 12 & 4.2 & 0.66 \\
\hline
\end{tabular}

Notes: All ixekizumab-treated participants received $160 \mathrm{mg}$ loading dose upfront; $17 \%$ had moderate to severe psoriasis and received ixekizumab 80 mg every 2 weeks up to week 12 and ixekizumab $80 \mathrm{mg}$ every 4 weeks thereafter; $83 \%$ without at least moderate psoriasis received ixekizumab 80 mg every 4 weeks after the initial loading dose (dosing regimens consistent with the label). Up to 24 weeks, there were no deaths, no occurrences of major cardiovascular adverse events, no inflammatory bowel disease, and no active or latent TB. P-values between adalimumab and ixekizumab were calculated using the two-sided Fisher exact test. Significant $\mathrm{p}$-values $(<0.05)$ are in bolded font.

Abbreviations: TEAEs, treatment emergent adverse events; NMSC, non-melanoma skin cancer; IXE, ixekizumab; IXEQ4W/IXEQ2W, ixekizumab 80 mg every 4 or every 2 weeks; ADA, adalimumab. 
Table 3 Treatment Emergent Adverse Events in III8 Persons with PsA Exposed to Ixekizumab for Up to 3 Years

\begin{tabular}{|c|c|c|}
\hline Safety Outcomes up to 3 Years $^{33}$ & $\begin{array}{c}\text { Ixekizumab Exposed } \\
(\mathrm{N}=\text { I I I } 8 \text { Subjects in Total }) \\
\text { Number of Subjects/People Affected Out } \\
\text { of Total }\end{array}$ & $\begin{array}{c}\text { Ixekizumab Exposed } \\
(\%) \\
\text { Percentage of Subjects/People Affected Out } \\
\text { of Total }\end{array}$ \\
\hline $\begin{array}{l}\text { Deaths (none were adjudicated as } \\
\text { related to ixekizumab) }\end{array}$ & 6 & 0.54 \\
\hline Major Acute Cardiovascular events & 11 & 0.98 \\
\hline Fatal MACE & 2 & 0.18 \\
\hline Non-fatal myocardial infarction & 5 & 0.45 \\
\hline Non-fatal stroke & 4 & 0.36 \\
\hline Coronary artery disease & 3 & 0.27 \\
\hline $\begin{array}{l}\text { Cerebrovascular accident leading to } \\
\text { treatment discontinuation }\end{array}$ & 2 & 0.18 \\
\hline $\begin{array}{l}\text { Malignancy (all considered SAE and led to } \\
\text { discontinuation of the drug) }\end{array}$ & 14 & 1.25 \\
\hline Non-melanoma skin cancer & 8 & 0.72 \\
\hline Breast cancer & 2 & 0.18 \\
\hline Prostate cancer & 1 & 0.09 \\
\hline Malignant melanoma in situ & I & 0.09 \\
\hline Metastatic renal cell carcinoma & I & 0.09 \\
\hline Papillary thyroid cancer & 1 & 0.09 \\
\hline Upper respiratory infection & 161 & 14.40 \\
\hline Nasopharyngitis & 150 & 13.42 \\
\hline Injection site reactions & 142 & 12.70 \\
\hline Injection site erythema & 52 & 4.65 \\
\hline Injection site pain & 18 & 1.61 \\
\hline $\begin{array}{l}\text { Injection site reactions leading to } \\
\text { treatment discontinuation }\end{array}$ & 3 & 0.27 \\
\hline Bronchitis & 81 & 7.25 \\
\hline $\begin{array}{l}\text { Bronchitis categorized as serious } \\
\text { infection }\end{array}$ & 4 & 0.36 \\
\hline Candida infections & 39 & 3.49 \\
\hline Esophageal candidiasis & 2 & 0.18 \\
\hline Depression & 29 & 2.59 \\
\hline Latent TB & 19 & 1.70 \\
\hline $\begin{array}{l}\text { Latent TB leading to treatment } \\
\text { discontinuation }\end{array}$ & 6 & 0.54 \\
\hline
\end{tabular}


Table 3 (Continued).

\begin{tabular}{|c|c|c|}
\hline Safety Outcomes up to 3 Years $^{33}$ & $\begin{array}{c}\text { Ixekizumab Exposed } \\
(\mathrm{N}=\text { I I I } 8 \text { Subjects in Total }) \\
\text { Number of Subjects/People Affected Out } \\
\text { of Total }\end{array}$ & $\begin{array}{c}\text { Ixekizumab Exposed } \\
(\%) \\
\text { Percentage of Subjects/People Affected Out } \\
\text { of Total }\end{array}$ \\
\hline Localized herpes zoster & 15 & 1.34 \\
\hline $\begin{array}{l}\text { Grade } 3 \text { neutropenia }<1000 \text { and }>500 \\
P M N / \mathrm{mm}^{3}\end{array}$ & 6 & 0.54 \\
\hline Cholelithiasis & 5 & 0.45 \\
\hline $\begin{array}{l}\text { Pneumonia categorized as serious } \\
\text { infection }\end{array}$ & 5 & 0.45 \\
\hline $\begin{array}{l}\text { Pneumonia leading to treatment } \\
\text { discontinuation }\end{array}$ & 2 & 0.18 \\
\hline Bronchitis & 4 & 0.36 \\
\hline $\begin{array}{l}\text { Myalgia leading to treatment } \\
\text { discontinuation }\end{array}$ & 2 & 0.18 \\
\hline Adjudicated IBD with no prior history & 2 & 0.18 \\
\hline $\begin{array}{l}\text { Septic arthritis leading to treatment } \\
\text { discontinuation }\end{array}$ & 1 & 0.09 \\
\hline $\begin{array}{l}\text { Hepatitis B leading to treatment } \\
\text { discontinuation }\end{array}$ & 1 & 0.09 \\
\hline $\begin{array}{l}\text { Cellulitis leading to treatment } \\
\text { discontinuation }\end{array}$ & 1 & 0.09 \\
\hline $\begin{array}{l}\text { Dermatitis leading to treatment } \\
\text { discontinuation }\end{array}$ & 1 & 0.09 \\
\hline $\begin{array}{l}\text { Otitis media leading to treatment } \\
\text { discontinuation }\end{array}$ & 1 & 0.09 \\
\hline $\begin{array}{l}\text { Tooth abscess leading to treatment } \\
\text { discontinuation }\end{array}$ & 1 & 0.09 \\
\hline $\begin{array}{l}\text { Urinary tract infection leading to } \\
\text { treatment discontinuation }\end{array}$ & 1 & 0.09 \\
\hline $\begin{array}{l}\text { Subcutaneous abscess leading to } \\
\text { treatment discontinuation }\end{array}$ & 1 & 0.09 \\
\hline $\begin{array}{l}\text { Tonsillitis leading to treatment } \\
\text { discontinuation }\end{array}$ & 1 & 0.09 \\
\hline
\end{tabular}

Powering the study to detect differences between TEAE Efficacy Using the occurrences would have required a much larger sample size.

Safety analyses in PsA, up to 3 years in a population of 1118 subjects with PsA exposed to ixekizumab used person-year estimation of incidence rates per 100 person years (PY). ${ }^{33} \mathrm{~A}$ frequency/prevalence calculation is represented in Table 3 and includes all events reported. ${ }^{33}$

\section{GRAPPA-OMERACT Domains}

Efficacy in psoriatic arthritis is best understood and applied to clinical scenarios using the itemized GRAPPA-OMERACT core domain set, due to disease heterogeneity and multidomain involvement. ${ }^{2,34}$ However, as required by the FDA, it is reported as composite ACR responses ${ }^{20,22,23,31}$ which are 
then supplemented by reporting efficacy for additional psoriatic disease-specific domains: dactylitis, enthesitis, psoriasis, and symptom and life impact measures. ${ }^{35}$ Primary efficacy data are highlighted in Table 4 for biologic-naïve PsA and in Table 5 for TNFi-experienced PsA.

\section{ACR20 Responses}

Notably, in biologic-naïve PsA (SPIRIT-P1), the ACR20 responses at 24 weeks with ixekizumab doses $80 \mathrm{mg}$ every 4 weeks or every 2 weeks ranged from $57.9 \%$ to $62.1 \%$ versus $30.2 \%$ in the placebo arm $(p<0.001)$ and were comparable to ACR20 responses of $57.4 \%$ in the active control arm treated with adalimumab $40 \mathrm{mg}$ every 2 weeks (direct comparison not powered, adalimumab vs placebo p-value $<0.001){ }^{23}$ In direct comparison ixekizumab versus adalimumab, ACR20 responses were not statistically different, achieved at week 24 by $68.9 \%$ with ixekizumab and $72.1 \%$ with adalimumab in the SPIRIT-H2H trial. ${ }^{7}$

In contrast, in TNFi-experienced individuals with PsA, ACR20 responses at 24 weeks were about 10 percentage points lower than in biologic-naïve PsA, as shown in the SPIRIT-P2 study: $48-53 \%$ versus $19 \%$ in the placebo arm $(p<0.0001) .^{22}$ It should be noted that placebo response was also lower in TNFi experienced participants. At 52weeks, ACR20 responses were similar between biologicnaïve $(67-70 \%)^{26}$ and TNFi-experienced (75-84\%) PsA patients. $^{29}$

\section{ACR50 Responses}

In biologic naïve PsA ixekizumab treatment yielded between $40.2 \%$ and $46.6 \%$ ACR50 responses versus $15.1 \%$ with placebo $(\mathrm{p}<0.001)$, while active control adalimumab yielded 38.6\% ACR50 responders ( $\mathrm{p}<$ 0.001 vs placebo). ${ }^{23}$ SPIRIT $\mathrm{H} 2 \mathrm{H}$, which was powered to detect a difference in the combined ACR50+PASI100 responses between the two active treatment arms, reported about $10 \%$ higher ACR50 response rates than SPIRIT-P1: ACR50 achieved by $50.5 \%$ taking ixekizumab $80 \mathrm{mg}$ every 4 weeks, which was not statistically different from $46.6 \%$ in the adalimumab $40 \mathrm{mg}$ every 2 weeks arm. Taking the combined primary outcome of ACR50+PASI100 response, this was met by $36 \%$ of ixekizumab-treated versus $27.9 \%$ of adalimumab-treated participants with a significant p-value of $0.036 .^{7}$ It should be noted that the combined endpoint of ACR50 +PASI100 has not been validated as a PsA outcome.

In TNFi-experienced PsA, ACR50 responses were observed in about a third of participants (33-35\%) on ixekizumab compared to $5 \%$ in the placebo arm (p-value $<0.001) .^{22}$ At 52-week follow-up, with no placebo control arm available, as those patients crossed over to treatment arms at the end of double blind, 40.6-53.4\% of TNFexperienced patients maintained ACR50, ${ }^{29}$ similar with results achieved in the biologic-naïve PsA (48.9-52.9\%). ${ }^{26}$

\section{ACR70 Responses}

At 24 weeks ACR70 response rates were 23.4-34\% with ixekizumab doses and $25.7 \%$ with adalimumab, versus $5.7 \%$ with placebo in biologic-naïve PsA $(\mathrm{p}<0.001){ }^{23}$ In SPIRIT-H2H, there were similar ACR70 responses at 24 weeks with ixekizumab and adalimumab (31.8\% vs $25.8 \%, \mathrm{p}=0.11) .^{7}$ In TNFi-experienced PsA, ACR70 response rates were $12-22 \%$ with ixekizumab doses versus absence of ACR70 response in the placebo arm (p-value $<$ $0.0001)^{22}$

At 52 weeks, ACR70 responses were $34-35 \%$ in biologic naïve PsA, ${ }^{26}$ whereas in TNFi experienced PsA, ACR70 responses were overall maintained at 20-32\% with ixekizumab. ${ }^{29}$

\section{Arthritis}

Joint count trajectories, unfortunately, are not required to be separately reported and therefore they are missing from clinical trial reports. Thresholds of $20 / 50 / 70 \%$ responses in $66 / 68$ tender and swollen joints counts are implicit in the ACR responses reviewed above. A responder definition/ minimal clinically important improvement in swollen/tender joint counts at individual level has not been defined which prevents reporting of patient-level meaningful improvement in arthritis.

Resolution of joint counts (100\% improvement) is rarely reported, although clinically relevant and important to patients. It appears to be less stringent than ACR70 for swollen joint counts, the opposite being true for tender joint counts, especially in biologic experienced PsA. ${ }^{36,37}$ Resolution of tender/swollen joint counts has not been reported with ixekizumab.

\section{Enthesitis}

In biologic naïve patients, resolution of enthesitis (Leeds Enthesitis Index/LEI $=0$ ) was reported also at 12 weeks (earlier than the pre-specified 24 weeks endpoint) and was $27.9 \%$ with ixekizumab every 4 weeks, which was not statistically significant compared to $28.1 \%$ resolution in the placebo arm; however, at 12 weeks, resolution of enthesitis occurred in $47.4 \%$ with ixekizumab every 2 
Table 4 Ixekizumab Efficacy in Biologic-Naïve Psoriatic Arthritis (SPIRIT-PI, SPIRIT-H2H)

\begin{tabular}{|c|c|c|c|c|c|c|c|}
\hline \multirow{3}{*}{$\begin{array}{l}\text { Outcomes } \\
\text { Timeline }\end{array}$} & PBO & \multicolumn{2}{|c|}{ IXEQ4WK } & \multicolumn{2}{|c|}{ IXEQ2WK } & \multicolumn{2}{|c|}{ ADA } \\
\hline & \multicolumn{2}{|c|}{24 Weeks } & \multirow{2}{*}{$\begin{array}{l}52 \text { Weeks } \\
\begin{array}{l}N=\left.19\right|^{26} \\
N=283\end{array}\end{array}$} & \multirow{2}{*}{$\begin{array}{c}24 \text { Weeks } \\
\begin{array}{c}\mathrm{N}=103 \\
-\end{array}\end{array}$} & \multirow{2}{*}{$\begin{array}{c}52 \text { Weeks } \\
N=190^{26} \\
-\end{array}$} & \multirow{2}{*}{$\begin{array}{c}24 \text { Weeks } \\
\begin{array}{c}N=101 \\
N=283\end{array}\end{array}$} & \multirow{2}{*}{$\begin{array}{c}52 \text { Weeks } \\
- \\
N=283\end{array}$} \\
\hline & $\begin{array}{c}N=106 \\
-\end{array}$ & $\begin{array}{l}N=107 \\
N=283\end{array}$ & & & & & \\
\hline $\begin{array}{l}\text { ACR20 (\%) } \\
\text { SPIRIT-PI } \\
\text { H2 } 2 \mathrm{H}^{7,31}\end{array}$ & $\begin{array}{c}30.2 \\
-\end{array}$ & $\begin{array}{l}57.9 \\
68.9\end{array}$ & $\begin{array}{l}66.5 \\
69.6\end{array}$ & $\begin{array}{c}62.1 \\
-\end{array}$ & $\begin{array}{c}66.8 \\
-\end{array}$ & $\begin{array}{l}57.4 \\
72.1\end{array}$ & $\begin{array}{c}- \\
68.9\end{array}$ \\
\hline $\begin{array}{l}\text { ACR50 (\%) } \\
\text { SPIRIT-PI } \\
\text { H2 } 2 \mathrm{H}^{7,31}\end{array}$ & $\begin{array}{c}\text { I5.I } \\
-\end{array}$ & $\begin{array}{l}40.2 \\
50.5\end{array}$ & $\begin{array}{l}52.9 \\
49.8\end{array}$ & $\begin{array}{c}46.6 \\
-\end{array}$ & $\begin{array}{c}48.9 \\
-\end{array}$ & $\begin{array}{l}38.6 \\
46.6\end{array}$ & $\begin{array}{c}- \\
49.8\end{array}$ \\
\hline $\begin{array}{l}\text { ACR70 (\%) } \\
\text { SPIRIT-PI } \\
\text { H2 } 2 \mathrm{H}^{7,31}\end{array}$ & $\begin{array}{c}5.7 \\
-\end{array}$ & $\begin{array}{l}23.4 \\
31.8\end{array}$ & $\begin{array}{l}33.5 \\
35.3\end{array}$ & $\begin{array}{c}34.0 \\
-\end{array}$ & $\begin{array}{c}34.7 \\
-\end{array}$ & $\begin{array}{l}25.7 \\
25.8\end{array}$ & $\begin{array}{c}- \\
34.3\end{array}$ \\
\hline $\begin{array}{l}\text { PASI75 (\%) } \\
\text { SPIRIT-PI } \\
\text { H2 } 2 \mathrm{H}^{7,31}\end{array}$ & $\begin{array}{c}10.34 \\
-\end{array}$ & $\begin{array}{l}71.2 \\
80.2\end{array}$ & 71.0 & $\begin{array}{c}79.7 \\
-\end{array}$ & $\begin{array}{c}73.5 \\
-\end{array}$ & $\begin{array}{l}54.4 \\
68.9\end{array}$ & - \\
\hline $\begin{array}{l}\text { PASI90 (\%) } \\
\text { SPIRIT-PI I } \\
\mathrm{H}_{2} \mathrm{H}^{7,31}\end{array}$ & $\begin{array}{c}6.0 \\
-\end{array}$ & $\begin{array}{l}56.2 \\
71.7\end{array}$ & $\begin{array}{l}58.8 \\
72.8\end{array}$ & $\begin{array}{c}67.8 \\
-\end{array}$ & $\begin{array}{c}66.7 \\
-\end{array}$ & $\begin{array}{l}36.8 \\
55.8\end{array}$ & $\begin{array}{c}- \\
54.1\end{array}$ \\
\hline $\begin{array}{l}\text { PASIIO0 (\%) } \\
\text { SPIRIT-PI I } \\
\text { H23 } \mathrm{H}^{7,31}\end{array}$ & $\begin{array}{c}3.0 \\
-\end{array}$ & $\begin{array}{l}42.5 \\
60.1\end{array}$ & $\begin{array}{l}48.9 \\
64.3\end{array}$ & $\begin{array}{c}52.5 \\
-\end{array}$ & $\begin{array}{c}55.6 \\
-\end{array}$ & $\begin{array}{l}23.5 \\
46.6\end{array}$ & $\begin{array}{c}- \\
41.3\end{array}$ \\
\hline $\begin{array}{l}\text { Enthesitis resolution, LEI=0 } \\
\text { SPIRIT-PI I } \\
\mathrm{H}^{23,26} \mathrm{H}^{7,31}\end{array}$ & $\begin{array}{c}19.3 \\
-\end{array}$ & $\begin{array}{l}42.6 \\
59.7\end{array}$ & $\begin{array}{l}51.3 \\
61.6\end{array}$ & $\begin{array}{c}38.6 \\
-\end{array}$ & $\begin{array}{c}42.6 \\
-\end{array}$ & $\begin{array}{l}33.3 \\
55.1\end{array}$ & $\begin{array}{c}- \\
57.1\end{array}$ \\
\hline $\begin{array}{l}\text { Dactylitis resolution, LDI=0 } \\
\text { SPIRIT-PI I,26 } \\
\mathrm{H} 2 \mathrm{H}^{7,31}\end{array}$ & $\begin{array}{c}25.0 \\
-\end{array}$ & $\begin{array}{l}79.5 \\
88.1\end{array}$ & $\begin{array}{l}81.1 \\
83.3\end{array}$ & $\begin{array}{c}76.9 \\
-\end{array}$ & $\begin{array}{c}75.0 \\
-\end{array}$ & $\begin{array}{l}77.8 \\
93.1\end{array}$ & $\begin{array}{c}- \\
81.0\end{array}$ \\
\hline $\begin{array}{l}\text { HAQ-DI MCID } \\
\text { SPIRIT-PI }{ }^{23,26} \\
\mathrm{H}_{2} \mathrm{H}^{7,31}\end{array}$ & $\begin{array}{c}26.1 \\
-\end{array}$ & $\begin{array}{l}49.0 \\
66.7\end{array}$ & $\begin{array}{l}55.0 \\
66.7\end{array}$ & 57.8 & 50.6 & $\begin{array}{l}49.4 \\
65.4\end{array}$ & $\begin{array}{c}- \\
64.6\end{array}$ \\
\hline Pain VAS MCID ${ }^{a, 32}$ & 35.6 & 61.2 & - & 71.1 & - & - & - \\
\hline Fatigue NRS MCID ${ }^{c, 32}$ & 20.4 & 36.8 & - & 40.5 & - & - & - \\
\hline
\end{tabular}

Notes: ${ }^{\text {PPain }}$ VAS MCID defined as $\geq 10 \mathrm{~mm} / 100$ improvement in patients with baseline pain $\geq 10$; ${ }^{\mathrm{b}} \mathrm{HAQ}$-DI MCID defined as improvement from baseline $\geq 0.35$ in patients with baseline score $\geq 0.35$; ' Fatigue NRS MCID defined as $\geq 3$ points $/ 10$ improvement in patients with baseline fatigue score $\geq 3$.

Abbreviations: PBO, placebo; IXE, ixekizumab; IXEQ4W/IXEQ2W, ixekizumab $80 \mathrm{mg}$ every 4 or every 2 weeks; ADA, adalimumab; ACR20/50/70, 20/50/70\% American College of Rheumatology responses; PASI75/90/I00, 75/90//00\% Psoriasis Area and Severity Index responses; LEI=0, Leeds Enthesitis Index = 0; LDI-B=0, Leeds Dactylitis Index-Basic = 0; VAS, Visual Analog Scale; MCID, Minimal Clinically important Difference; HAQ-DI, Health Assessment Questionnaire-Disability Index; NRS, Numeric Rating Scale.

weeks ( $p<0.01$ compared to placebo). ${ }^{23}$ At 24 weeks (pre-specified primary outcome timeline), both ixekizumab treatment arms showed significant enthesitis improvement with $42.6 \%$ resolution (ixekizumab every 4 weeks, $\mathrm{p}<$ 0.01 ) and $38.6 \%$ resolution (ixekizumab every 2 weeks, $\mathrm{p}<0.025)$, versus placebo $19.3 \%$. The active control arm treated with adalimumab achieved $33.3 \%$ resolution of enthesitis, which was not significant versus placebo. ${ }^{23}$

There was maintenance of enthesitis responses at 52 weeks (51.3\% and $42.6 \%$, respectively). ${ }^{26}$ Compared head 
Table 5 Ixekizumab Efficacy in TNFi-Experienced Psoriatic Arthritis (SPIRIT-P2)

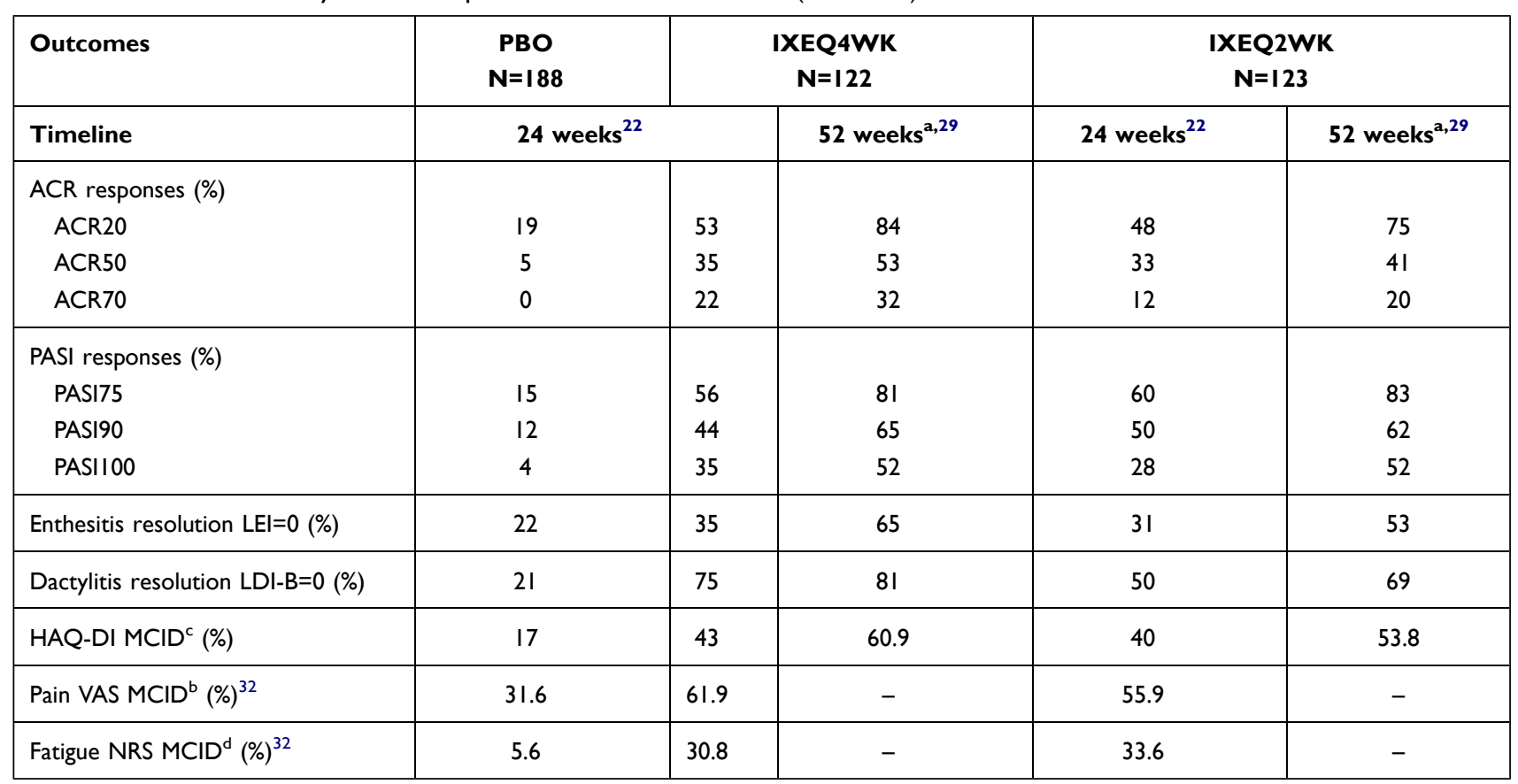

Notes: a Multiple imputation ${ }^{\text {b}}$ Pain VAS MCID defined as $\geq 10 \mathrm{~mm} / 100$ improvement in patients with baseline pain $\geq 10$; ${ }^{b} \mathrm{HAQ}-\mathrm{DI}$ MCID defined as improvement from baseline $\geq 0.35$ in patients with baseline score $\geq 0.35$; ${ }^{\circ}$ Fatigue NRS MCID defined as $\geq 3$ points/ 10 improvement in patients with baseline fatigue score $\geq 3$.

Abbreviations: PBO, placebo; IXE, ixekizumab; IXEQ4W/IXEQ2W, ixekizumab $80 \mathrm{mg}$ every 4 or every 2 weeks; ADA, adalimumab; ACR20/50/70, 20/50/70\% American College of Rheumatology responses; PASI75/90/I00, 75/90/I00\%, Psoriasis Area and Severity Index responses; LEI=0, Leeds Enthesitis Index $=0$; LDI-B=0, Leeds Dactylitis Index-Basic = 0; VAS,Visual Analog Scale; MCID, Minimal Clinically important Difference, HAQ-DI, Health Assessment Questionnaire-Disability Index; NRS, Numeric Rating Scale.

to head with adalimumab, in a biologic naïve population, there was no difference in enthesitis resolution by LEI at 24 or 52 weeks. Resolution determined by SPARCC enthesitis index occurred more often with ixekizumab than with adalimumab at 24 weeks $(56.6 \%$ vs $45 \%, \mathrm{p}=0.019)$, though there was no difference at 52 weeks. ${ }^{7,31}$

In TNFi-experienced patients, there was no statistically significant difference in enthesitis resolution versus placebo with either ixekizumab treatment regimen at 24 weeks. $^{22}$ At 52 weeks, enthesitis resolution was reported in $64.5 \%$ and $53.4 \%{ }^{29}$ In a post-hoc analysis of enthesitis resolution with ixekizumab in the combined TNFi naïve and experienced population, resolution at each LEI site ranged from $45 \%$ to $49 \%{ }^{24}$

In summary, data from two controlled studies (P1 and $\mathrm{H} 2 \mathrm{H})$ demonstrate two practical points: 1) in a biologic naïve PsA population with active enthesitis, IL-17 inhibition with ixekizumab may be more advantageous over TNF inhibition with adalimumab, and 2) in a biologic naïve PsA population with active enthesitis and concomitant moderate to severe psoriasis, selecting the ixekizumab dermatology dosing regimen over the PsA regimen may lead to faster enthesitis resolution.

\section{Dactylitis}

In biologic naïve PsA, there was no difference in resolution of dactylitis (LDI-B=0) at the early 12 weeks analysis with either ixekizumab regimen, related to a high rate of resolution (53.6\%) in the placebo arm; however, the mean change in LDI-B was significant versus placebo $(-36.3)$ with ixekizumab every 4 weeks $(-72.8, \mathrm{p}<0.001)$ and every 2 weeks $(-63.9, \mathrm{p}<0.05)$. At 24 weeks, resolution of dactylitis was more likely to occur with both ixekizumab treatment arms $(79.5 \%$ and $76.9 \%$, both $\mathrm{p}<0.001$ versus placebo $25 \%)^{23}$ and was maintained at 52 weeks ( $81.1 \%$ and $75 \%$, respectively). ${ }^{26}$ When compared head to head with adalimumab, there was no difference in dactylitis resolution with ixekizumab at 24 or 52 weeks $(88.1 \%$ versus $93.1 \%$; and 83.35 versus $81 \%)^{7,31}$

At 24 weeks in TNFi-experienced PsA, resolution of dactylitis occurred more frequently with ixekizumab every 4 weeks $(75 \%, p=0.003)$ or ixekizumab every 2 weeks $(50 \%, \mathrm{p}=0.06)$ versus placebo $(21 \%)$. The mean change in LDI-B score was not statistically significant in either arm $(-34.7$ and -32.1$)$, since a similar reduction was reported in the placebo arm $(-36.2) .^{22}$ 
In a post-hoc integrated analysis versus placebo at 24 weeks, there was resolution of dactylitis in $78 \%$ with ixekizumab every 4 weeks and $65 \%$ with ixekizumab every 2 weeks versus placebo $24 \%$ (nominal p-values versus placebo $<0.001) .{ }^{24}$

\section{Spine Symptoms}

The BASDAI questionnaire was reported in TNFiexperienced PsA in mean improvements were significant and greater versus placebo. ${ }^{30}$ This is difficult to interpret as the prevalence of axial disease was not collected, and the BASDAI is known to improve in both axial and peripheral PsA. However, ixekizumab has an approved label for the treatment of both axial spondyloarthritis and established ankylosing spondylitis, based on efficacy in these diseases.

\section{Skin Disease Activity}

In biologic-naïve PsA, PASI75 was achieved in $71.2 \%$ and $79.7 \%$ with ixekizumab every 4 and 2 weeks, respectively, and in $54.4 \%$ with adalimumab, all significant versus $10.4 \%$ with placebo ( $\mathrm{p} \leq 0.001$ for each). PASI90 was achieved in $56.2 \%$ and $67.8 \%$ with ixekizumab and in $36.8 \%$ with adalimumab, all significant versus $6 \%$ with placebo ( $\mathrm{p} \leq 0.001$ for each). PASI100 remission of psoriasis was achieved in $42.5 \%$ and $52.5 \%$ with ixekizumab every 4 and 2 weeks, respectively, and in $23.5 \%$ with adalimumab, all significant versus $1.5 \%$ with placebo ( $\mathrm{p} \leq 0.001$ for each ixekizumab arm, $\mathrm{p}<0.01$ for adalimumab). All PASI responses were established at similar magnitude and significance at 12 weeks. Improvement in nail psoriasis measured using mean decreases in the NAPSI score at 24 weeks were similarly significant at group level versus placebo ( -14 and -15.5 versus -2.4 , $\mathrm{p}<0.001){ }^{23}$

PASI100 remission was a major secondary endpoint in the direct comparison study of ixekizumab versus adalimumab and was achieved at 24 weeks by $60.1 \%$ and $46.6 \%$, respectively $(\mathrm{p}=0.001){ }^{7}$ At 52 weeks, it was maintained by $64.3 \%$ and $41.3 \%$, respectively $(\mathrm{p}<$ $0.001){ }^{31}$

In TNFi-experienced PsA, at 24 weeks, PASI75 responses were achieved in $56 \%$ with ixekizumab every 4 weeks and in $60 \%$ with ixekizumab every 2 weeks statistically significant versus $15 \%$ with placebo $(\mathrm{p}<$ 0.0001 for both comparisons). PASI90 responses were achieved in $44 \%$ and in 50\% with ixekizumab, statistically significant versus $12 \%$ with placebo $(\mathrm{p}<0.0001$ for both comparisons). Remission of psoriasis measured as PASI100 response was achieved in 35\% with ixekizumab every 4 weeks and in $28 \%$ with ixekizumab every 2 weeks statistically significant versus $4 \%$ with placebo $(p=0.0001$ and $p=0.0006$, respectively). Improvement in nail psoriasis measured using mean decreases in the NAPSI score at 24 weeks were similarly significant at group level versus placebo $(-10.5$ and -12.5 versus $+1, \mathrm{p}<0.0001){ }^{22}$

\section{Pain}

Joint pain, as assessed by visual analog scale (VAS, 0-100, 100 is worst pain), was evaluated in a post-hoc analysis in which a minimal clinically important improvement was defined as $10 \%$ improvement. The percentage of biologicnaïve patients with $10 \%$ or higher-level improvement in pain VAS at 24 weeks was between $61 \%$ and $71 \%$ with ixekizumab versus $36 \%$ with placebo (nominal p-values $<$ 0.01). In TNFi-experienced PsA, at 24 weeks, $62-56 \%$ obtained $10 \%$ or higher-level improvement versus $32 \%$ with placebo (nominal p-values $<0.01$ ). ${ }^{32}$ A pain improvement threshold of $10 \%$ in VAS is small and may not be relevant to all patients. For example, the acceptable pain level state included in the minimal disease activity definition is a pain score of $\leq 15 \mathrm{~mm} / 100 \mathrm{~mm}$, and most participants in the trials were much more than $10 \%$ higher above this threshold.

\section{Patient Global}

There is not an MCID threshold defined for this measure, which represents the patient's global impression of their disease status on a scale of $0-100,100$ being the worst. If a numerical rating scale is used the range is $0-10$ and interpretation in the same direction. As guidance, the patient global assessment state included in the PsA minimal disease activity definition is a score of $\leq 20 \mathrm{~mm} /$ $100 \mathrm{~mm}$. Patient global assessment (PatGA) VAS was assessed at baseline and 24 weeks and was reported separately in a post-hoc analysis. Indirectly reported in the primary analyses, PatGA is a criterion included in the calculation of all ACR responses. In biologic naïve patients, PatGA VAS at baseline was $61-63 \mathrm{~mm}$ and decreased by -33.8 and -35.6 with ixekizumab (both p-values $<0.001$ versus placebo -14.8) at 24 weeks. TNFi-experienced patients had similar improvements with PatGA VAS reduction by -40.7 and -37.3 (both $\mathrm{p}<$ 0.001 versus placebo -19$)$ at 24 weeks. ${ }^{32}$ 


\section{Physical Function}

In biologic-naïve PsA, HAQ-DI MCID response (a decrease in individual HAQ-DI score of 0.35 or more) was achieved at 24 weeks by $49 \%$ and $57.8 \%$ with ixekizumab (both $\mathrm{p}<0.001$ ) versus placebo $26.1 \%$. In the adalimumab active control group, a comparable 49.4\% also achieved HAQ-DI MCID $(\mathrm{p}<0.001$ versus placebo). ${ }^{23}$ HAQ-DI responses were of similar magnitude and significance versus placebo also at the earlier 12-week timepoint. In biologic-naïve PsA, direct comparison ixekizumab versus adalimumab showed HAQ-DI responses were similar with both treatments, $66.7 \%$ and $65.4 \%$, respectively, achieving and improvement of 0.35 points or more ${ }^{7}$ which was maintained at 52 weeks $(66.7 \%$ and $64.6 \%)^{31}$

In TNFi-experienced PsA, HAQ-DI MCID response was achieved by $40-43 \%$ versus $17 \%$ in the placebo arm (p-values $<0.001)^{22}$ and maintained at week $52 .{ }^{29}$

\section{Life Impact/Quality of Life}

In biologic-naïve patients, both ixekizumab treatment arms significantly outperformed placebo in most SF-36 domains, including physical functioning, role physical, bodily pain, general health, vitality (only significant vs placebo for ixekizumab every 2 weeks), social functioning, and role emotional at 12 and 24 weeks. Most of these were also significant with adalimumab versus placebo, except social functioning. Changes in the SF-36 mental health domain were not significant versus placebo with either ixekizumab dose or with adalimumab. Improvements in the Physical Component score (SF-36 PCS) were significant versus placebo for both ixekizumab doses and adalimumab. This was not the case for the Mental Component score (SF-36 MCS), although the same domains are used to calculate both these scores, only differently weighted. ${ }^{23,27}$ Interestingly, in TNFiexperienced patients significant improvements versus placebo were observed at 24 weeks with both ixekizumab doses in the SF-36 PCS (8.9 and 8.2 points versus 3.3 points, p-values $<0.0001)$ as well as the SF-36 MCS (3.6 and 4 points versus 0.9 points, p-values 0.02 and 0.009 respectively). ${ }^{22}$

\section{Fatigue}

A threshold for minimal clinically important improvement in fatigue in PsA was defined in the ixekizumab datasets as an individual improvement of 3 points $^{38}$ on the fatigue numerical rating scale ranging from 0 to 10,10 being the worst. With this caveat, the threshold was also used to report post-hoc ixekizumab efficacy on fatigue in the same dataset in which it was derived. In biologic-naïve patients, the proportion of patients achieving the minimal clinically important improvement was $36.8 \%(\mathrm{p}<0.05)$ and $40.5 \%$ $(\mathrm{p}<0.01)$ at 24 weeks with ixekizumab every 4 and every 2 weeks, respectively, versus $20.4 \%$ with placebo. In TNFi-experienced patients, the proportion of patients achieving the minimal clinically important improvement was $30.8 \%$ and $33.6 \%$ with each ixekizumab regimen at 24 weeks, versus $5.6 \%$ with placebo (p-value versus placebo $<0.001$ for both). ${ }^{32}$

\section{Systemic Inflammation}

Inflammatory markers were not reported separately. They were considered in the calculation of all ACR responses.

\section{Radiographic Damage Progression}

Progression of structural damage in biologic-naïve PsA was measured by changes from the baseline in the modified Total Sharp Score (mTSS) using the percentage of patients without radiographic progression at weeks 16, 24, 52, 108 and 156. At weeks 16 and 24 there was statistically significant less radiographic progression versus placebo in both ixekizumab treatment arms versus placebo, which translated into a statistically significant higher proportion of patients on ixekizumab with less radiographic progression versus placebo at 24 weeks $^{23}$ which was maintained over time. At 52 weeks, there was no radiographic progression $(\mathrm{mTSS} \leq 0)$ in $71-82 \%$ treated with ixekizumab, and with follow-up through 156 weeks, there was no radiographic progression in $61-71 \%$. Similar findings at 156 weeks were seen with mTSS $\leq 0.5(69-79 \%)$ and $\operatorname{mTSS} \leq 1.85(81-87 \%){ }^{28}$

\section{Patient Phenotypes}

Eligible participants in the ixekizumab RCTs were selected based on the Classification for Psoriatic Arthritis (CASPAR) classification criteria. ${ }^{39}$ All patients in the RCTs had a documented rheumatologist diagnosis of PsA for at least 6 months fulfilling the criteria and had active psoriatic arthritis as defined by the presence of at least 3 swollen joints (out of 66 joints) and at 3 least tender joints (out of 68 joints). They were all adults aged 18 or older. Other variable inclusion criteria between the two studies are presented by study in Table 6 .

Participant characteristics are summarized in Table 7. Participants were majority white with much lower 
Table 6 Notable Inclusion Criteria in Clinical Trials of Ixekizumab

\begin{tabular}{|l|c|c|c|}
\hline Inclusion Criteria & SPIRIT-P I ${ }^{\mathbf{2 3}}$ & $\begin{array}{c}\text { SPIRIT } \\
\text { H2H }^{\mathbf{7}}\end{array}$ \\
\hline Erosions (radiographic) & $\begin{array}{c}\text { Yes (or CRP elevation), hand or foot; } \\
\text { centrally read }\end{array}$ & Unspecified \\
\hline Active plaque psoriasis & No & Yes & Unspecified \\
\hline $\begin{array}{l}\text { Inflammatory marker elevation } \\
\text { (CRP>6 mg/L) }\end{array}$ & Yes (or erosions on radiography) & Ynspecified \\
\hline $\begin{array}{l}\text { Prior treatment with csDMARDs } \\
\text { Prior treatment with bDMARD }\end{array}$ & Unspecified & Yes, I or more & Yes, I or \\
more
\end{tabular}

Abbreviations: CRP, C-reactive protein; csDMARDs, classical synthetic disease modifying anti-rheumatic drugs; bDMARDs, biologic DMARDs; TNFi, tumor necrosis factor alpha inhibitor.

representation for Asian (2-12\%) and minimal American Indian or Alaska native, while there was no representation of African American subjects. On average, age across treatment and placebo groups was 50 years, and there were more women in the placebo-controlled trials, compared to more men in the head-to-head trial. Weight averages ranged from 82 to $92 \mathrm{~kg}$, and BMI values 2932. Across intervention arms, PsA disease duration ranged from 6 to 10 years, and psoriasis duration 13-17 years. Prevalence of methotrexate use ranged from $34 \%$ to $59 \%$ and was highest in the head-to-head trial. Majority had active psoriasis $(92-100 \%)$ as well as moderate psoriasis (BSA $>3 \%$ ) in 55-100\%. In the head-to-head trial, all had at least moderate psoriasis. Dactylitis prevalence was highest in the SPIRIT-P1 study (23-51\%) and much lower in the other two trials $(12-23 \%)$. More than half had enthesitis at baseline $(52-68 \%)$. The range of mean swollen joint counts was 7-13, whereas tender joint counts 13-25 and these were close to twice as high in the TNFiexperienced PsA population. Mean CRP was above normal range (close to twice or higher).

\section{Discussion}

Ixekizumab was administered to 1118 participants with PsA across three controlled trials, and data up to three years of safety and efficacy data were reported to date. The most frequent TEAEs were infections, occurring in about a third of participants and overall comparable to placebo. Serious infections occurred in up to $2.2 \%$ in the most intensive dosing regimen of ixekizumab $80 \mathrm{mg}$ every 2 weeks. Directly compared to ixekizumab, adalimumab had higher serious adverse events, which were $8.5 \%$ and $12.4 \%$ with adalimumab versus $3.5 \%$ and $4.2 \%$ with ixekizumab $(\mathrm{p}=0.02, \mathrm{p}<0.01)$ at weeks 24 and 52, respectively, in the SPIRIT-H2H trial.

Compared to placebo, ixekizumab was associated with statistically significant more injection site reactions and allergic or hypersensitivity reactions in both the TNFinaïve and TNFi-experienced populations. Compared to adalimumab, ixekizumab was associated with significantly more any TEAEs and significantly more injection site reactions. Up to three years adverse events with ixekizumab, listed in descending order of prevalence included upper respiratory infections (14.4\%), nasopharyngitis $(13.4 \%)$, injection site reactions $12.7 \%$ ), bronchitis $7.25 \%$ ), injection site erythema $4.65 \%$ ), candida infections (3.49\%), depression (2.59\%), injection site pain $(1.61 \%)$, localized herpes zoster 1.34\%), and malignancy (inclusive of nonmelanoma skin cancer) $(1.25 \%)$.

A systematic review of allergic and hypersensitivity reactions with biological agents in psoriatic disease concluded that there are consistent reports of a switch from psoriasis to an atopic eczema phenotype in patients taking biologics inhibiting TNF alpha and the interleukin (IL)-17/ IL-23 axis. $^{41}$ This biological mechanism is plausibly responsible for a portion of the allergic and sensitivity reactions reported here.

In terms of ixekizumab efficacy, ACR response levels were comparable to adalimumab active control and adalimumab direct control in two studies; while in TNFiexperienced ACR responses with corresponding ixekizumab doses were 5-10 percentage points lower than in 
Table 7 Participant Baseline Characteristics in Ixekizumab Clinical Trials

\begin{tabular}{|c|c|c|c|c|}
\hline Characteristic* & PBO & IXEQ4WK & IXEQ2WK & ADAQ2WK \\
\hline \multicolumn{5}{|l|}{ Numbers } \\
\hline SPIRIT-PI $I^{23,26}$ & $N=106$ & $N=107$ & $N=103$ & $N=101$ \\
\hline $\mathrm{H} 2 \mathrm{H}^{7,31}$ & - & $N=283$ & - & $N=283$ \\
\hline SPIRIT-P2 ${ }^{40}$ & $N=118$ & $N=122$ & $N=123$ & - \\
\hline \multicolumn{5}{|l|}{ Age, Mean (yrs) } \\
\hline SPIRIT-PI I 23,26 & 51 & 49 & 50 & 49 \\
\hline $\mathrm{H} 2 \mathrm{H}^{7,31}$ & - & 48 & - & 48 \\
\hline SPIRIT-P2 ${ }^{40}$ & 52 & 53 & 52 & - \\
\hline \multicolumn{5}{|l|}{ Women, \% } \\
\hline SPIRIT-PI I 23,26 & 55 & 58 & 53 & 49 \\
\hline $\mathrm{H} 2 \mathrm{H}^{7,31}$ & - & 43 & - & 47 \\
\hline SPIRIT-P2 ${ }^{40}$ & 53 & 48 & 59 & - \\
\hline \multicolumn{5}{|l|}{ Weight, Mean (kg) } \\
\hline SPIRIT-PI I ${ }^{23,26}$ & 84 & 86 & 82 & 92 \\
\hline $\mathrm{H} 2 \mathrm{H}^{7,31}$ & - & 85 & - & 82 \\
\hline SPIRIT-P2 ${ }^{40}$ & 91 & 90 & 85 & - \\
\hline \multicolumn{5}{|l|}{ BMI, Mean $\left(\mathrm{kg} / \mathrm{m}^{2}\right)$} \\
\hline SPIRIT-PI ${ }^{23,26}$ & 29 & 30 & 29 & 32 \\
\hline $\mathrm{H} 2 \mathrm{H}^{7,31}$ & - & 30 & - & 30 \\
\hline SPIRIT-P2 ${ }^{40}$ & 32 & 31 & 30 & - \\
\hline \multicolumn{5}{|l|}{ Race, \% } \\
\hline \multicolumn{5}{|l|}{ White } \\
\hline SPIRIT-PI $I^{23,26}$ & 93 & 95 & 93 & 94 \\
\hline $\mathrm{H} 2 \mathrm{H}^{7,31}$ & - & 78 & - & 75 \\
\hline SPIRIT-P2 ${ }^{40}$ & 92 & 91 & 93 & - \\
\hline \multicolumn{5}{|l|}{ Asian } \\
\hline SPIRIT-PI I 23,26 & 5 & 2 & 5 & 3 \\
\hline $\mathrm{H} 2 \mathrm{H}^{7,31}$ & - & 10 & - & 12 \\
\hline SPIRIT-P2 ${ }^{40}$ & 6 & 6 & 6 & - \\
\hline \multicolumn{5}{|c|}{ American Indian or Alaska native } \\
\hline SPIRIT-PI ${ }^{23,26}$ & 2 & 2 & 2 & 3 \\
\hline $\mathrm{H} 2 \mathrm{H}^{7,31}$ & - & 0 & - & 0 \\
\hline SPIRIT-P2 ${ }^{40}$ & 0 & 0 & 0 & - \\
\hline \multicolumn{5}{|l|}{ Other } \\
\hline SPIRIT-PI ${ }^{23,26}$ & 0 & I & 0 & 0 \\
\hline $\mathrm{H} 2 \mathrm{H}^{7,31}$ & - & 0 & - & 0 \\
\hline SPIRIT-P2 $2^{40}$ & 3 & 3 & 2 & - \\
\hline \multicolumn{5}{|c|}{ PsA duration, Mean (yrs) } \\
\hline SPIRIT-PI ${ }^{23,26}$ & 7 & 6 & 8 & 8 \\
\hline $\mathrm{H} 2 \mathrm{H}^{7,31}$ & - & 7 & - & 6 \\
\hline SPIRIT-P2 $2^{40}$ & 7 & 10 & 7 & - \\
\hline \multicolumn{5}{|c|}{ Psoriasis duration, Mean (yrs) } \\
\hline SPIRIT-PI ${ }^{23,26}$ & 16 & 17 & 17 & 16 \\
\hline $\mathrm{H} 2 \mathrm{H}^{7,31}$ & - & 13 & - & 13 \\
\hline SPIRIT-P2 ${ }^{40}$ & 15 & 16 & 17 & - \\
\hline
\end{tabular}


Table 7 (Continued).

\begin{tabular}{|c|c|c|c|c|}
\hline Characteristic* & PBO & IXEQ4WK & IXEQ2WK & ADAQ2WK \\
\hline $\begin{array}{l}\text { Methotrexate use, current, \% } \\
\text { SPIRIT-PI I3,26 } \\
\text { H2H } \\
\text { SPIRIT-P2 }{ }^{40}\end{array}$ & $\begin{array}{l}56 \\
- \\
34\end{array}$ & $\begin{array}{l}53 \\
59 \\
39\end{array}$ & $\begin{array}{l}52 \\
- \\
50\end{array}$ & $\begin{array}{l}56 \\
60 \\
-\end{array}$ \\
\hline $\begin{array}{l}\text { Active psoriasis (\%) } \\
\text { SPIRIT-PI }{ }^{23,26} \\
\mathrm{H}_{2} \mathrm{H}^{7,31} \\
\text { SPIRIT-P2 }^{40}\end{array}$ & $\begin{array}{l}96 \\
- \\
92\end{array}$ & $\begin{array}{l}94 \\
100 \\
97\end{array}$ & $\begin{array}{l}92 \\
- \\
92\end{array}$ & $\begin{array}{l}96 \\
100 \\
-\end{array}$ \\
\hline $\begin{array}{l}\text { Psoriasis } \leq 3 \% \\
\text { SPIRIT-PI } \\
\text { H2H,26 } \\
\text { SPIRIT-P2 } \\
\text { S0 }\end{array}$ & $\begin{array}{l}68 \\
- \\
57\end{array}$ & $\begin{array}{l}73 \\
100 \\
56\end{array}$ & $\begin{array}{l}65 \\
- \\
55\end{array}$ & $\begin{array}{l}72 \\
100 \\
-\end{array}$ \\
\hline $\begin{array}{l}\text { Any current nail psoriasis, } \% \\
\text { SPIRIT-PI } \\
\text { H}^{23,26} \mathrm{H}^{7,31} \\
\text { SPIRIT-P2 } \\
\text { S0 }\end{array}$ & $\begin{array}{l}70 \\
- \\
62\end{array}$ & $\begin{array}{l}65 \\
68 \\
73\end{array}$ & $\begin{array}{l}72 \\
- \\
60\end{array}$ & $\begin{array}{l}70 \\
63 \\
-\end{array}$ \\
\hline $\begin{array}{l}\text { Dactylitis, current, \% } \\
\text { SPIRIT-PI }{ }^{23,26} \\
\mathrm{H}_{2} \mathrm{H}^{7,31} \\
\text { SPIRIT-P2 }^{40}\end{array}$ & $\begin{array}{l}37 \\
- \\
12\end{array}$ & $\begin{array}{l}51 \\
15 \\
23\end{array}$ & $\begin{array}{l}40 \\
- \\
16\end{array}$ & $\begin{array}{l}23 \\
21\end{array}$ \\
\hline $\begin{array}{l}\text { Enthesitis, current, \% } \\
\text { SPIRIT-PI } \\
\text { H } 23,26^{7,31} \\
\text { SPIRIT-P2 }{ }^{40}\end{array}$ & $\begin{array}{l}54 \\
- \\
58\end{array}$ & $\begin{array}{l}65 \\
56 \\
56\end{array}$ & $\begin{array}{l}57 \\
- \\
68\end{array}$ & $\begin{array}{l}55 \\
52 \\
-\end{array}$ \\
\hline $\begin{array}{l}\text { Swollen joint count (out of } 66 \text { ), Mean } \\
\text { SPIRIT-PI I3,26 } \\
\text { H2H } \text { H }^{7,31} \\
\text { SPIRIT-P2 }\end{array}$ & $\begin{array}{l}7 \\
- \\
10\end{array}$ & $\begin{array}{l}8 \\
8 \\
13\end{array}$ & $\begin{array}{l}7 \\
- \\
14\end{array}$ & $\begin{array}{l}7 \\
8 \\
-\end{array}$ \\
\hline $\begin{array}{l}\text { Tender joint count (out of } 68 \text { ), Mean } \\
\text { SPIRIT-PI } \\
\text { H2H,26 } \\
\text { SPIRIT-P2 }{ }^{70}\end{array}$ & $\begin{array}{l}13 \\
- \\
23\end{array}$ & $\begin{array}{l}14 \\
13 \\
22\end{array}$ & $\begin{array}{l}14 \\
- \\
25\end{array}$ & $\begin{array}{l}13 \\
15 \\
-\end{array}$ \\
\hline $\begin{array}{l}\text { Disability HAQ-DI, Mean } \\
\text { SPIRIT-PI } \\
\mathrm{H}^{23,26} \mathrm{H}^{7,31} \\
\text { SPIRIT-P2 }^{40}\end{array}$ & $\begin{array}{l}1.2 \\
- \\
1.2\end{array}$ & $\begin{array}{l}1.2 \\
1.2 \\
1.2\end{array}$ & $\begin{array}{l}1.2 \\
- \\
1.2\end{array}$ & $\begin{array}{l}1.1 \\
1.3 \\
-\end{array}$ \\
\hline $\begin{array}{l}\text { Inflammation, CRP, Mean (mg/L) } \\
\text { SPIRIT-PI } \\
\text { H2H,26 } \\
\text { SPIRIT-P2 } \\
\text { S0 }\end{array}$ & $\begin{array}{l}15 \\
- \\
12\end{array}$ & $\begin{array}{l}13 \\
10 \\
17\end{array}$ & $\begin{array}{l}15 \\
- \\
14\end{array}$ & $\begin{array}{l}13 \\
11 \\
-\end{array}$ \\
\hline
\end{tabular}

Note: *Values are rounded to the nearest whole number.

Abbreviations: PBO, placebo; IXE, ixekizumab; IXEQ4W/IXEQ2W, ixekizumab 80 mg every 4 or every 2 weeks; ADA, adalimumab; ADAQ2W, adalimumab 40 mg every 2 weeks; HAQ-DI, Health Assessment Questionnaire-Disability Index; CRP, C-reactive protein. 
TNFi-naïve PsA. Efficacy for PsA manifestations overall was most optimistic in the head-to-head ixekizumab versus adalimumab study, which was a biologic-naïve PsA population and an open-label design, except for enthesitis remission, which showed maximum improvement in the TNFi experienced population (65\%) and is generally less predictable than other responses due to the pain component. Complete remission of psoriasis (PASI100) was possible in up to $64 \%$ in TNFi-naïve and up to $52 \%$ of TNFiexperienced PsA at 52 weeks. Specifically for enthesitis, a more rapid response could perhaps be achieved with every 2-week dosing as seen in SPIRI-P1. A strategy to consider for patients with psoriatic arthritis who also have moderate to severe psoriasis is to prescribe the dermatologic dosing regimen (160 mg upfront, $80 \mathrm{mg}$ every 2 weeks for 12 weeks, then $80 \mathrm{mg}$ every 4 weeks) over the psoriatic arthritis (160 mg upfront, then $80 \mathrm{mg}$ every 4 weeks) dosing regimen.

In terms of population characteristics, ixekizumab was studied in middle-aged people, with balance proportion of men and women, who had a PsA duration of about 7 years and psoriasis duration of about 15 years, and who were on average at the BMI threshold between overweight and obesity $\left(30 \mathrm{~kg} / \mathrm{m}^{2}\right)$. Ixekizumab studies had no representation of African Americans, and the prevalence of Hispanic or Latino study subjects was not reported. In terms of PsA characteristics joint counts were on average 7 out of 66 for swollen and 13 out of 68 for tender, enthesitis affected $60 \%$, dactylitis $12-51 \%$, psoriasis $92-100 \%$. Of the study subjects $34-60 \%$ were concomitantly on methotrexate.

This review has limitations in that it only considered published peer review articles reporting primary and longterm results of phase III controlled ixekizumab trials, and by having access to reported data only, not individual participant data. However, by extracting data across the entire ixekizumab PSA program, we observed results were consistent, and differences between TNFi-naïve and experienced populations were in the expected direction, as well as differences between outcomes by study design (double-blind versus open label).

\section{Conclusion}

Ixekizumab treatment in PsA was associated with a statistically significant higher risk of injection site reactions when compared to placebo or adalimumab. Ixekizumab had statistically significantly fewer serious adverse events than adalimumab. Efficacy was demonstrated for all PsA disease activity domains as well as for slowing radiographic disease progression with ixekizumab. The main shortcoming of the ixekizumab PsA program is lack of representation of African American study participants.

\section{Acknowledgments}

Dr John Miller is a Jerome L. Greene Foundation Scholar and is supported by a Jerome L. Greene Foundation Scholar Award.

Dr Abin P. Puravath was supported by a fellowship training grant from the National Institutes of Health (NIH) under award number T32-AR048522.

Dr Ana-Maria Orbai is a Jerome L. Greene Foundation Scholar and is supported in part by a research grant from the National Institute of Arthritis and Musculoskeletal and Skin Diseases (NIAMS) of the National Institutes of Health (NIH) under award number P30-AR070254 (Core B).

\section{Disclosure}

Dr John Miller and Dr Abin P Puravath report no conflicts of interest in this work.

Dr Ana-Maria Orbai received research grant support to Johns Hopkins University from AbbVie, Amgen, Celgene, Eli Lilly, Gilead, Horizon, Janssen, and Novartis, and received personal consulting fees from Bristol Myers Squibb, Eli Lilly, Janssen, Novartis, Pfizer, and UCB.

\section{References}

1. Ritchlin CT, Colbert RA, Gladman DD. Psoriatic arthritis. $N$ Engl J Med. 2017;376(21):2095-2096. doi:10.1056/NEJMc1704342

2. Gossec L, Baraliakos X, Kerschbaumer A, et al. EULAR recommendations for the management of psoriatic arthritis with pharmacological therapies: 2019 update. Ann Rheum Dis. 2020;79(6):700-712. doi:10.1136/annrheumdis-2020-217159

3. Singh JA, Guyatt G, Ogdie A, et al. Special article: 2018 American college of rheumatology/national psoriasis foundation guideline for the treatment of psoriatic arthritis. Arthritis Care Res. 2019;71(1):2-29. doi:10.1002/acr.23789

4. Coates LC, Kavanaugh A, Mease PJ, et al. Group for research and assessment of psoriasis and psoriatic arthritis 2015 treatment recommendations for psoriatic arthritis. Arthritis Rheumatol Hoboken NJ. 2016;68(5):1060-1071. doi:10.1002/art.39573

5. Yan D, Blauvelt A, Dey AK, et al. New frontiers in psoriatic disease research, part II: comorbidities and targeted therapies. $J$ Invest Dermatol. 2021. doi:10.1016/j.jid.2021.02.743

6. Food and Drug Administration. Ixekizumab label. Available from: https://www.accessdata.fda.gov/drugsatfda_docs/label/2021/ 125521s014lbl.pdf. Accessed July 6, 2021.

7. Mease PJ, Smolen JS, Behrens F, et al. A head-to-head comparison of the efficacy and safety of ixekizumab and Adalimumab in biologicalnaïve patients with active psoriatic arthritis: 24-week results of a randomised, open-label, blinded-assessor trial. Ann Rheum Dis. 2020;79(1):123-131. doi:10.1136/annrheumdis-2019-215386 
8. Kolls JK, Lindén A. Interleukin-17 family members and inflammation. Immunity. 2004;21(4):467-476. doi:10.1016/j. immuni.2004.08.018

9. McGeachy MJ, Cua DJ, Gaffen SL. The IL-17 family of cytokines in health and disease. Immunity. 2019;50(4):892-906. doi:10.1016/j. immuni.2019.03.021

10. Li X, Bechara R, Zhao J, McGeachy MJ, Gaffen SL. IL-17 receptor-based signaling and implications for disease. Nat Immunol. 2019;20(12):1594-1602. doi:10.1038/s41590-019-0514-y

11. Benham H, Norris P, Goodall J, et al. Th17 and Th22 cells in psoriatic arthritis and psoriasis. Arthritis Res Ther. 2013;15(5): R136. doi:10.1186/ar4317

12. Menon B, Gullick NJ, Walter GJ, et al. Interleukin- $17+\mathrm{CD} 8+\mathrm{T}$ cells are enriched in the joints of patients with psoriatic arthritis and correlate with disease activity and joint damage progression. Arthritis Rheumatol. 2014;66(5):1272-1281. doi:10.1002/art.38376

13. Steel KJA, Srenathan U, Ridley M, et al. ArthritisPolyfunctional, proinflammatory, tissue-resident memory phenotype and function of synovial interleukin-17A+CD8+ $\mathrm{T}$ cells in psoriatic. Arthritis Rheumatol. 2020;72(3):435-447. doi:10.1002/art.41156

14. Penkava F, Mdc V-H, Young Md, et al. Single-cell sequencing reveals clonal expansions of pro-inflammatory synovial CD8 T cells expressing tissue-homing receptors in psoriatic arthritis. Nat Commun. 2020;11(1):4767. doi:10.1038/s41467-020-18513-6

15. Leijten EF, Kempen TS, Olde Nordkamp MA, et al. Tissue-resident memory CD8+ T cells from skin differentiate psoriatic arthritis from psoriasis. Arthritis Rheumatol. 2021;73(7):1220-1232. doi:10.1002/ art. 41652

16. Chabaud M, Durand JM, Buchs N, et al. Human interleukin-17: a T cell-derived proinflammatory cytokine produced by the rheumatoid synovium. Arthritis Rheum. 1999;42(5):963-970. doi:10.1002/15290131(199905)42:5<963::AID-ANR15>3.0.CO;2-E

17. Vitiello GA, Miller G. Targeting the interleukin-17 immune axis for cancer immunotherapy. $J$ Exp Med. 2020;217(1):e20190456. doi:10.1084/jem.20190456

18. Zhao J, Chen X, Herjan T, Li X. The role of interleukin-17 in tumor development and progression. J Exp Med. 2020;217(1):e20190297. doi:10.1084/jem.20190297

19. Armstrong AW, Read C. Pathophysiology, clinical presentation, and treatment of psoriasis: a review. JAMA. 2020;323(19):1945-1960. doi:10.1001/jama.2020.4006

20. McInnes IB, Behrens F, Mease PJ, et al. Secukinumab versus Adalimumab for treatment of active psoriatic arthritis (EXCEED): a double-blind, parallel-group, randomised, active-controlled, Phase 3b trial. Lancet Lond Engl. 2020;395(10235):1496-1505. doi:10.1016/ S0140-6736(20)30564-X

21. Liu L, Lu J, Allan BW, et al. Generation and characterization of ixekizumab, a humanized monoclonal antibody that neutralizes interleukin-17A. J Inflamm Res. 2016;9:39-50. doi:10.2147/JIR. S100940

22. Nash P, Kirkham B, Okada M, et al. Ixekizumab for the treatment of patients with active psoriatic arthritis and an inadequate response to tumour necrosis factor inhibitors: results from the 24-week randomised, double-blind, placebo-controlled period of the SPIRIT-P2 phase 3 trial. Lancet Lond Engl. 2017;389(10086):2317-2327. doi:10.1016/S0140-6736(17)31429-0

23. Mease PJ, van der Heijde D, Ritchlin CT, et al. Ixekizumab, an interleukin-17A specific monoclonal antibody, for the treatment of biologic-naive patients with active psoriatic arthritis: results from the 24-week randomised, double-blind, placebo-controlled and active (Adalimumab)-controlled period of the phase III trial SPIRIT-P1. Ann Rheum Dis. 2017;76(1):79-87. doi:10.1136/annrheumdis-2016-209709

24. Gladman DD, Orbai AM, Klitz U, et al. Ixekizumab and complete resolution of enthesitis and dactylitis: integrated analysis of two phase 3 randomized trials in psoriatic arthritis. Arthritis Res Ther. 2019;21(1):38. doi:10.1186/s13075-019-1831-0
25. Tillett W, Lin C-Y, Trevelin Sprabery A, Birt JA, Kavanaugh A. Clinically meaningful improvement in work productivity loss in active psoriatic arthritis: post-hoc analysis of SPIRIT-P1 and SPIRIT-P2 trials. Clin Exp Rheumatol. 2020;38(6):1227-1230.

26. van der Heijde D, Gladman DD, Kishimoto M, et al. Efficacy and safety of ixekizumab in patients with active psoriatic arthritis: 52-week results from a phase III study (SPIRIT-P1). J Rheumatol. 2018;45(3):367-377. doi:10.3899/jrheum.170429

27. Gottlieb AB, Strand V, Kishimoto M, et al. Ixekizumab improves patient-reported outcomes up to 52 weeks in bDMARD-naïve patients with active psoriatic arthritis (SPIRIT-P1). Rheumatol Oxf Engl. 2018;57(10):1777-1788. doi:10.1093/rheumatology/key161

28. Chandran V, van der Heijde D, Fleischmann RM, et al. Ixekizumab treatment of biologic-naïve patients with active psoriatic arthritis: 3 -year results from a phase III clinical trial (SPIRIT-P1). Rheumatol Oxf Engl. 2020;59(10):2774-2784. doi:10.1093/rheumatology/ kez684

29. Genovese MC, Combe B, Kremer JM, et al. Safety and efficacy of ixekizumab in patients with PsA and previous inadequate response to TNF inhibitors: week 52 results from SPIRIT-P2. Rheumatol Oxf Engl. 2018;57(11):2001-2011. doi:10.1093/rheumatology/key182

30. Kavanaugh A, Marzo-Ortega H, Vender R, et al. Ixekizumab improves patient-reported outcomes in patients with active psoriatic arthritis and inadequate response to tumour necrosis factor inhibitors: SPIRIT-P2 results to 52 weeks. Clin Exp Rheumatol. 2019;37 (4):566-574.

31. Smolen JS, Mease P, Tahir H, et al. Multicentre, randomised, openlabel, parallel-group study evaluating the efficacy and safety of ixekizumab versus Adalimumab in patients with psoriatic arthritis naïve to biological disease-modifying antirheumatic drug: final results by week 52. Ann Rheum Dis. 2020;79(10):1310-1319. doi:10.1136/annrheumdis-2020-217372

32. Orbai A-M, Gladman DD, Goto H, et al. Rapid and sustained improvements in patient-reported signs and symptoms with ixekizumab in biologic-naive and TNF-inadequate responder patients with psoriatic arthritis. Clin Exp Rheumatol. 2021;39(2):329-336.

33. Combe B, Rahman P, Kameda H, et al. Safety results of ixekizumab with 1822.2 patient-years of exposure: an integrated analysis of 3 clinical trials in adult patients with psoriatic arthritis. Arthritis Res Ther. 2020;22(1):14. doi:10.1186/s13075-020-2099-0

34. Orbai A-M, de Wit M, Mease $\mathrm{P}$, et al. International patient and physician consensus on a psoriatic arthritis core outcome set for clinical trials. Ann Rheum Dis. 2017;76(4):673-680. doi:10.1136/ annrheumdis-2016-210242

35. Kalyoncu U, Ogdie A, Campbell W, et al. Systematic literature review of domains assessed in psoriatic arthritis to inform the update of the psoriatic arthritis core domain set. RMD Open. 2016;2(1): e000217. doi:10.1136/rmdopen-2015-000217

36. Orbai A-M, McInnes IB, Coates LC, et al. Effect of secukinumab on the different GRAPPA-OMERACT core domains in psoriatic arthritis: a pooled analysis of 2049 patients. J Rheumatol. 2019. doi: $10.3899 /$ jrheum. 190507

37. Orbai A-M, Husni ME, Gladman DD, et al. Secukinumab efficacy on psoriatic arthritis GRAPPA-OMERACT core domains in patients with or without prior tumor necrosis factor inhibitor use: pooled analysis of four phase 3 studies. Rheumatol Ther. 2021;8 (3):1223-1240. doi:10.1007/s40744-021-00337-5

38. Gladman D, Nash P, Goto H, et al. Fatigue numeric rating scale validity, discrimination and responder definition in patients with psoriatic arthritis. RMD Open. 2020;6:1. doi:10.1136/rmdopen2019-000928

39. Taylor W, Gladman D, Helliwell P, et al. Classification criteria for psoriatic arthritis: development of new criteria from a large international study. Arthritis Rheum. 2006;54(8):2665-2673. doi:10.1002/ art. 21972 
40. Nash P, Behrens F, Orbai A-M, et al. Ixekizumab is efficacious when used alone or when added to conventional synthetic disease-modifying antirheumatic drugs (cDMARDs) in patients with active psoriatic arthritis and previous inadequate response or intolerance to tumour necrosis factor inhibitors. RMD Open. 2018;4(2): e000692. doi:10.1136/rmdopen-2018-000692
41. Al-Janabi A, Foulkes AC, Mason K, Smith CH, Griffiths CEM, Warren RB. Phenotypic switch to eczema in patients receiving biologics for plaque psoriasis: a systematic review. $J$ Eur Acad Dermatol Venereol. 2020;34(7):1440-1448. doi:10.1111/jdv.16246

\section{Publish your work in this journal}

The Journal of Inflammation Research is an international, peerreviewed open-access journal that welcomes laboratory and clinical findings on the molecular basis, cell biology and pharmacology of inflammation including original research, reviews, symposium reports, hypothesis formation and commentaries on: acute/chronic inflammation; mediators of inflammation; cellular processes; molecular mechanisms; pharmacology and novel anti-inflammatory drugs; clinical conditions involving inflammation. The manuscript management system is completely online and includes a very quick and fair peerreview system. Visit http://www.dovepress.com/testimonials.php to read real quotes from published authors.

Submit your manuscript here: https://www.dovepress.com/journal-of-inflammation-research-journal 